\title{
EFEKTIVITAS PERASAN DAUN JERUK NIPIS (Citrus aurantifolia) TERHADAP KEMATIAN LARVA Aedes aegypti INSTAR III DI LABORATORIUM LOKA LITBANG P2B2 CIAMIS JAWA BARAT TAHUN 2017
}

\author{
Ratu Monica ${ }^{1}$ ), Khomsatun ${ }^{2}$ ) \\ Jurusan Kesehatan Lingkungan, Politeknik Kesehatan Kemenkes Semarang, \\ Jl.Raya Baturaden KM 12 Purwokerto, Indonesia
}

\begin{abstract}
Abstrak
Demam Berdarah Dengue adalah penyakit menular disebabkan oleh virus dengue yang ditularkan ke manusia melalui gigitan nyamuk Aedes aegypti dan Aedes albopictus.Salah satu pengendalian vektornya yaitu dengan membunuh larvanya.Cara yang dapat digunakan secara alami yaitu menggunakan perasan daun jeruk nipis yang mengandung bahan beracun yang disebut limonoida, maka dapat berfungsi sebagai larvasida.Metode yang digunakan dalam penelitian ini adalah quasi experiment (eksperimen semu).Analisis statistik yang digunakan Anova one way dengan uji lanjut LSD (Least Significant Difference) dan uji Probit. Hasil Penelitian kematian Larva Aedes aegypti konsentrasi 10\% dapat membunuh larva 14,66\%, pada konsentrasi $20 \%$ dapat membunuh larva 38,66\%, dan pada konsentrasi $30 \%$ dapat membunuh larva 70,66 \%. Konsentrasi perasan daun jeruk nipis yang diteliti hanya dapat membunuh larva dengan prosentase paling tinggi yaitu 70,66\%. Jadi, dari berbagai konsentrasi yang diteliti tidak ada yang efektif, karena Standar Pengujian Efikasi Pestisida konsentrasi yang efektif $>90 \%$.Simpulan dari penelitian ini adalah perasan daun jeruk nipis mampu membunuh larva 70,66\% dengan konsentrasi 30\%. Direkomendasikan dapat membunuh 50\% dari sampel larva Aedes aegypti adalah konsentrasi 23.499 \% dan konsentrasi larvasida perasan daun jeruk nipis (Citrus aurantifolia) yang dapat membunuh 90\% dari sampel larva Aedes aegypti adalah konsentrasi $37.466 \%$. Ada beda yang bermakna antara berbagai konsentrasi terhadap kematian larva Aedes aegypti.
\end{abstract}

Kata kunci: perasan daun jeruk nipis, larvasida, larva Aedes aegypti,kesehatan lingkungan.

\begin{abstract}
Dengue fever is an infectious disease caused by dengue viruses are transmitted to humans through the bites of mosquitoes Aedes aegypti and Aedes albopictus. One control whose vectors i.e. by killing the larvae are. How that can be used in a natural, i.e. using the juice of lemon leaves containing poisonous material called limonoida, then it can serve as a larvasida. The methods used in this research was quasi experiment (experiment of the artificial). Statistical analysis used one-way Anova with advanced test LSD (Least Significant Difference) test and Probit. The research results of the death of the larvae of Aedes aegypti 10\% concentrations can kill the larvae 14.66\%, at concentrations of $20 \%$ can kill the larvae $38.66 \%$, and at a concentration of $30 \%$ can kill the larvae $70.66 \%$. The concentration of the juice of the leaves of lemon that examined just can kill the larvae with the highest percentage of IE $70.66 \%$. So, from a wide range of concentrations examined, there is no effective, because of the concentration of pesticide Efficacy Testing Standards effective $>90 \%$. Summary of the research is the juice of the leaves of the lime to kill larvae $70.66 \%$ with $30 \%$ concentration. Recommended can kill $50 \%$ of a sample of larvae of Aedes aegypti is the concentration and concentration of larvasida\% 23,499 juice leaf lime (Citrus aurantifolia) that can kill 90\% of the samples of larvae of Aedes aegypti is the concentration of 37,466\%. There is a meaningful difference between the various concentration against the death of the larvae of Aedes aegypti.
\end{abstract}

Key words:leaf juice of lime, larvasida, the larvae of Aedes aegypti, the health of the environment. 


\section{Pendahuluan}

Menurut Permenkes RI No 374/ MENKES/

PER/ III/ 2010 pengendalian vektor adalah semua kegiatan atau tindakan yang ditujukan untuk menurunkan populasi vektor serendah mungkin, sehingga keberadaannya tidak lagi berisiko untuk terjadinya penularan penyakit yang disebabkan oleh vektor disuatu wilayah, sehingga penularan penyakit yang disebabkan oleh vektor dapat dicegah. Salah satu penyakit yang ditularkan oleh vektor nyamuk Aedes aegypti adalah Demam Berdarah Dengue.

Nyamuk Aedes aegypti merupakan jenis nyamuk yang dapat membawa virus Dengue. Virus Dengue ditularkan kepada manusia melalui gigitan nyamuk Aedes aegypti, ditandai dengan demam mendadak, sakit kepala, nyeri belakang bola mata, mual dan manifestasi pendarahan seperti rumple lead positif, mimisan atau gusi berdarah

Laporan Kementerian Kesehatan mencatat di Indonesia tahun 2015 pada bulan Oktober ada 3.219 kasus Demam Berdarah Dengue (DBD) dengan kematian mencapai 32 jiwa, bulan November ada 2.921 kasus dengan 37 kematian dan bulan Desember 1.104 kasus dengan 31 kematian. Dibandingkan dengan tahun 2014 pada bulan Oktober tercatat 8.149 kasus dengan 81 kematian, bulan November 7.877 kasus dengan 66 kematian dan Desember 7.856 kasus dengan 50 kematian.

Pengendalian penyakit demam berdarah dapat dilakukan dengan memberantas penyebab penyakit (virus dengue), isolasi penderita, mencegah gigitan nyamuk Aedes aegypti, dan pengendalian vektor. Upaya pengendalian perkembangan nyamuk Aedes aegypti telah banyak dilakukan, antara lain dengan cara kimia, cara fisik dan cara biologi. Penggunaan insektisida dari bahan kimia ternyata menimbulkan banyak masalah diantaranya pencemaran lingkungan seperti pencemaran air dan resistensi serangga terhadap insektisida, sehingga perlu adanya insektisida yang lebih aman bagi lingkungan, untuk mengurangi dampak negatif dari penggunaan insektisida kimia.

Metode yang dianggap paling efektif untuk mengendalikan nyamuk vektor demam berdarah adalah dengan cara membunuh jentik-jentiknya. Cara alternatif yang aman yaitu dengan menggunakan bahan alami dari tumbuhan.Hal ini dikarenakan bahan yang terbuat dari bahan alami yang mudah terurai (biodegradable) di alam sehingga tidak mencemari lingkungan serta relatif aman bagi manusia dan ternak peliharaan karena residunya mudah hilang.

${ }^{1)}$ E-mail: ratumonica90@gmail.com

${ }^{2)}$ E-mail: khomsatun1962@gmail.com
Lebih dari 2400 jenis tumbuhan yang termasuk ke dalam 255 famili dilaporkan mengandung bahan pestisida, salah satunya adalah jeruk nipis (Citrus aurantifolia).Jeruk nipis mengandung bahan beracun yang disebut limonoida.Senyawa dengan golongan terpenoid yaitu limonoida yang berfungsi sebagai larvasida.Limonoid adalah salah satu jenis senyawa bersifat racun yang dapat masuk kedalam tubuh larva Aedes aegypti melalui rendaman konsentrasi perasan daun jeruk nipis yang termakan.

\section{Bahan dan Metode}

Jenis penelitian ini adalahquasi experiment (eksperimen semu) karena penelitian ini variabelvariabel di dalam penelitian tidak dikendalikan sepenuhnya.Desain penelitian yang dipilih adalah Posttest Only Control Group Design.Peneliti mengambil rancangan penelitian eksperimen yang membandingkan kelompok eksperimen dengan kelompok kontrol.Cara pengumpulan data yang dilakukan dalam penelitian ini adalah perhitungan dan pengukuran langsung obyek yang diteliti. Perhitungan digunakan untuk mengetahui jumlah larva Aedes aegypti instar III yang mati. Pengukuran digunakan untuk mengetahui suhu air uji, $\mathrm{pH}$ air uji, suhu ruang penelitian dan kelembaban ruang penelitian. Data pendukung dikumpulkan dengan cara menanyakan dan mencatat profil yang ada di tempat penelitian.

\section{Hasil dan Pembahasan}

Berdasarkan hasil penelitian efektivitas perasan daun jeruk nipis terhadap kematian larva Aedes aegypti yang telah diamati didapatkan hasil sebagai berikut:

a. Pengukuran suhu air uji

Tabel 1. Distribusi Hasil Pengukuran Suhu Air Uji

\begin{tabular}{ccccc}
\hline No & Konsentrasi & Replikasi & \multicolumn{2}{c}{ Suhu air uji $\left({ }^{\circ} \mathrm{C}\right)$} \\
\cline { 3 - 5 } & & $\begin{array}{c}\text { Suhu } \\
\text { sebelu } \\
\text { m }\end{array}$ & $\begin{array}{c}\text { Suhu } \\
\text { sesudah }\end{array}$ \\
& & & 25 & 25 \\
\hline 1 & $5 \%$ & 1 & 25 & 25 \\
& & 2 & 25 & 25 \\
\hline 2 & $10 \%$ & 1 & 25 & 25 \\
& & 2 & 25 & 25 \\
& & 3 & 25 & 25 \\
\hline 3 & $15 \%$ & 1 & 25 & 25 \\
& & 2 & 25 & 25 \\
& & 3 & 25 & 25 \\
\hline & & & 25 & 25 \\
\hline
\end{tabular}

Hasil pengukuran suhu air uji sebelum dan sesudah penelitian perasan daun jeruk nipis selama 24 jam di Laboratorium Entomologi Loka Litbang P2B2 Ciamis didapatkan hasil suhu air uji sebelum dan sesudah dengan rata-rata $25 \quad{ }^{\circ} \mathrm{C}$.Suhu air mempengaruhi proses kehidupan larva Aedes aegypti. Perubahan suhu secara ekstrim merupakan keadaan yang tidak seimbang yang dapat mengganggu kehidupan larva. Berdasarkan hasil pengukuran suhu 
air uji sebelum dan sesudah pemberian perasan daun jeruk nipis pada masing-masing perlakuan dan kontrol pada tabel 1 dapat diketahui bahwa suhu rata-rata air uji sebelum pemberian perasan daun jeruk nipis adalah $25{ }^{\circ} \mathrm{C}$ dan suhu rata-rata setelah pemberian perasan daun jeruk nipis $25{ }^{\circ} \mathrm{C}$. Hal ini tidak menunjukan perbedaan yang ekstrim. Menurut Depkes (1992) suhu air yang optimal bagi kehidupan larva Aedes aegypti berkisar antara $25-30{ }^{\circ} \mathrm{C}$. Berarti suhu air selama penelitian masih sesuai dengan perindukan larva Aedes aegypti.

b. Pengukuran $\mathrm{pH}$ air uji

Tabel 2.Distribusi Hasil Pengukuran pH Air Uji

\begin{tabular}{ccccc}
\hline \multirow{2}{*}{ No } & Konsentrasi & Replikasi & \multicolumn{2}{c}{$\mathrm{pH}$ air uji } \\
\cline { 3 - 5 } & & $\begin{array}{c}\mathrm{pH} \text { air } \\
\text { sebelum }\end{array}$ & $\begin{array}{c}\mathrm{pH} \text { air } \\
\text { sesudah }\end{array}$ \\
\hline 1 & $5 \%$ & 1 & 6,90 & 6,56 \\
& & 2 & 6,90 & 6,56 \\
& & 3 & 6,90 & 6,56 \\
\hline 2 & $10 \%$ & 1 & 6,90 & 6,42 \\
& & 2 & 6,90 & 6,42 \\
& & 3 & 6,90 & 6,42 \\
\hline 3 & $15 \%$ & 1 & 6,90 & 6,36 \\
& & 2 & 6,90 & 6,36 \\
& & 3 & 6,90 & 6,36 \\
\hline & & & 6,90 & 6,45 \\
\hline
\end{tabular}

Hasil pengukuran $\mathrm{pH}$ air uji sebelum dan sesudah penelitian perasan daun jeruk nipis di Laboratorium Entomologi Loka Litbang P2B2 Ciamis didapatkan hasil $\mathrm{pH}$ air uji sebelum dengan rata-rata 6,90 dan $\mathrm{pH}$ air uji sesudah yaitu rata-rata 6,45, pH air uji menurun karena perasan daun jeruk nipis bersifat asam.Kelangsungan hidup larva dipengaruhi oleh $\mathrm{pH}$ air perindukan. Larva Aedes aegypti tahan hidup dalam suasana pH 6,8-8,5. Berdasarkan hasil pengukuran $\mathrm{pH}$ air uji sebelum dan sesudah pemberian perasan daun jeruk nipis pada tabel 2 dapat diketahui bahwa $\mathrm{pH}$ rata-rata air uji sebelum pemberian perasan daun jeruk nipis adalah 6,90 dan sesudah pemberian perasan daun jeruk nipis adalah 6,45. Hal ini menunjukan bahwa $\mathrm{pH}$ air mengalami perubahan antara $\mathrm{pH}$ sebelum dan sesudah pemberian perasan daun jeruk nipis, tetapi perubahannya masih sesuai dengan $\mathrm{pH}$ perindukan larva Aedes aegypti yaitu 6,88,5 (Adang Iskandar, 1985).

c. Pengukuran Suhu Ruangan Penelitian

Berdasarkan hasil pengukuran dapat diketahui bahwa rata-rata suhu udara diruang penelitian $27^{\circ} \mathrm{C}$, jadi masih dalam batas suhu perkembangbiakkan dan kehidupan nyamuk Aedes aegypti. Menurut Adang Iskandar (1985, h 161) bahwa nyamuk Aedes aegypti dapat hudup pada suhu berkisar antara $20^{\circ} \mathrm{C}$ sampai $30^{\circ} \mathrm{C}$, sehungga suhu udara $27^{\circ} \mathrm{C}$ masih dalam batas diterima sebagai tempat perindukkan nyamuk Aedes aegypti.

d. Pengukuran Kelembaban Udara Ruangan

Hasil pengukuran kelembaban udara ruangan penelitian selama 24 jam di laboratorium entomologi Loka Litbang P2B2 Ciamis. Pengukuran kelembaban
Udara Ruang Penelitian pada lokasi penelitian suhu ruang sudah diatur sedemikian rupa dengan menggunakan AC, sehingga kelembaban ruang setiap harinya sama, yaitu kelembaban ruang 87\%. Hasil pengukuran kelembaban udara ruangan yang digunakan untuk penelitian dengan menggunakan thermometer udara.

e. Jumlah larva Aedes aegypti yang mati

Tabel 3. Distribusi Hasil Pengamatan dan Perhitungan Kematian Larva Setelah Kontak dengan Perasan Daun Jeruk (Citrus aurantifolia)

\begin{tabular}{|c|c|c|c|c|}
\hline $\begin{array}{l}\text { Konsen } \\
\text { trasi } \\
\text { Perasan }\end{array}$ & Replikasi & $\begin{array}{c}\text { Jumlah } \\
\text { larva } \\
\text { uji } \\
\text { (ekor) } \\
\end{array}$ & $\begin{array}{c}\text { Jumlah } \\
\text { larva mati } \\
\text { (ekor) }\end{array}$ & $\begin{array}{c}\text { Prose } \\
\text { ntase } \\
(\%)\end{array}$ \\
\hline \multirow[t]{3}{*}{ Kontrol } & 1 & 25 & 0 & \multirow[t]{3}{*}{0} \\
\hline & 2 & 25 & 0 & \\
\hline & 3 & 25 & 0 & \\
\hline \multirow[t]{3}{*}{$5 \%$} & 1 & 25 & 4 & \multirow[t]{3}{*}{14,66} \\
\hline & 2 & 25 & 4 & \\
\hline & 3 & 25 & 3 & \\
\hline \multirow[t]{3}{*}{$10 \%$} & 1 & 25 & 7 & \multirow[t]{3}{*}{38,66} \\
\hline & 2 & 25 & 10 & \\
\hline & 3 & 25 & 12 & \\
\hline \multirow[t]{3}{*}{$15 \%$} & 1 & 25 & 21 & \multirow[t]{3}{*}{70,66} \\
\hline & 2 & 25 & 15 & \\
\hline & 3 & 25 & 17 & \\
\hline
\end{tabular}

Berdasarkan hasil pengamatan dan perhitungan jumlah larva Aedes aegypti yang mati pada perlakuan dan kontrol setelah dikontakkan dengan perasan daun jeruk nipis selama 24 jam dapat dilihat pada tabel 3 . tabel tersebut menunjukan bahwa jumlah kematian larva Aedes aegypti yaitu pada konsentrasi 5\% prosentasenya adalah $14,66 \%$, pada konsentrasi $10 \%$ prosentasenya adalah $38,66 \%$, pada konsentrasi $15 \%$ prosentasenya adalah 70,66\%.

f. Analisis Hasil Anova

Uji Analysis of Varians (Anova) bertujuan untuk menguji ke tiga varians mempunyai rata-rata (mean) yang sama. Dari perhitungan statistik Anova diketahui bahwa signifikan 0.000 yang berarti $<0.05$ maka Ha diterima atau ada perbedaan antara rata-rata kematian larva Aedes aegypti dari berbagai konsentrasi daun jeruk nipis yang diberikan. Setelah diketahui ada perbedaan yang signifikan antara berbagai konsentrasi dengan kontrol pemberian perasan daun jeruk nipis terhadap kematian larva Aedes aegypti.

\section{g. Analisis Uji Post Hoc Test LSD}

Hasil dari analisis uji post hoc test LSD diketahui bahwa dari 9 perbandingan antara berbagai konsentrasi perasan daun jeruk nipis yang diberikan terhadap kematian larva Aedes aegypti, didapatkan hasil signifikansinya $<0.05$ yang artinya Ha diterima, maka antara konsentrasi tersebut terdapat perbedaan 
yang bermakna. Pembahasan untuk masing-masing dosis sebagai berikut:

1) Konsentrasi 5\% dengan Konsentrasi $10 \%$

Berdasarkan hasil analisis dapat diketahui bahwa konsentrasi 5\% dengan konsentrasi $10 \%$ mempunyai tingkat signifikansi 0.005 .Hal tersebut signifikansinya $<0.05$, maka Ha diterima sehingga ada perbedaan yang bermakna antar konsentrasi dengan kematian larva Aedes aegypti.

2) Konsentrasi 5\% dengan Konsentrasi 15\%

Berdasarkan hasil analisis dapat diketahui bahwa Konsentrasi 5\% dengan Konsentrasi 15\% mempunyai tingkat signifikansi 0.000 .Hal tersebut signifikansinya $<0.05$, maka Ha diterima sehingga ada perbedaan yang bermakna antar konsentrasi dengan kematian larva Aedes aegypti.

3) Konsentrasi 10\% dengan Konsentrasi 15\%

Berdasarkan hasil analisis dapat diketahui bahwa Konsentrasi 10\% dengan Konsentrasi 15\% mempunyai tingkat signifikansi 0.001 .Hal tersebut signifikansinya $<0.05$, maka Ha diterima sehingga ada perbedaan yang bermakna antar konsentrasi dengan kematian larva Aedes aegypti.

h. Analisis Uji Probit

Tabel 4. Distribusi Hasil Uji Probit LC $_{50}$ dan LC $_{90}$

\begin{tabular}{cccc}
\hline \multicolumn{4}{c}{ 95\% Confidence Limits for dosis } \\
\hline $\begin{array}{c}\text { Probability } \\
\text { Bound }\end{array}$ & Estimate & $\begin{array}{l}\text { Lower } \\
\text { Bound }\end{array}$ & Upper \\
\hline .500 & 23.499 & 21.545 & 25.789 \\
\hline .900 & 37.466 & 33.897 & 42.763 \\
\hline
\end{tabular}

Uji LC50 dan LC90 adalah konsentrasi yang dibutuhkan untuk membunuh $50 \%$ dan $90 \%$ populasi dari larva uji. $\mathrm{LC}_{50}$ dan $\mathrm{LC}_{90}$ digunakan untuk menilai toksisitas dari larvasida. Nilai $\mathrm{LC}_{50}$ dan $\mathrm{LC}_{90}$ ditentukan berdasarkan jumlah kematian larva uji yang didapatkan pada masing-masing konsentrasi. Berdasarkan tabel 4. tentang kematian larva Aedes aegypti setelah dikontakkan dengan berbagai konsentrasi perasan daun jeruk nipis, maka diperoleh nilai LC $_{50}$ yang direkomendasikan sebesar $23.499 \%$ mampu membunuh larva Aedes aegypti sebesar 50 \% larva uji dengan konsentrasi 21.545 \% (batas bawah) dan konsentrasi $25.789 \%$ (batas atas) dan $\mathrm{LC}_{90}$ yang direkomendasikan sebesar $37.466 \%$ mampu membunuh larva Aedes aegypti sebesar 90 \% larva uji dengan konsentrasi $33.897 \%$ (batas bawah) dan konsentrasi $42.763 \%$ (batas atas).

i. Uji Keefektifan Kematian Larva Aedes aegypti

Tabel 4.8 Distribusi Prosentase Kematian Larva Aedes aegypti.

\begin{tabular}{ccccc}
\hline $\begin{array}{c}\text { Konsentr } \\
\text { asi } \\
\text { Perasan }\end{array}$ & $\begin{array}{c}\text { Replika } \\
\text { si }\end{array}$ & $\begin{array}{c}\text { Jumlah } \\
\text { larva uji } \\
\text { (ekor) }\end{array}$ & $\begin{array}{c}\text { Jumlah } \\
\text { larva } \\
\text { mati } \\
\text { (ekor) }\end{array}$ & $\begin{array}{c}\text { Prose } \\
\text { ntase } \\
\text { (\%) }\end{array}$ \\
\cline { 1 - 4 } Kontrol & 1 & 25 & 0 & \multirow{2}{*}{0} \\
\cline { 1 - 4 } & 2 & 25 & 0 & \\
\hline $5 \%$ & 3 & 25 & 0 & 14,66 \\
\hline
\end{tabular}

\begin{tabular}{lllll}
\hline & 2 & 25 & 4 & \\
\cline { 1 - 3 } & 3 & 25 & 3 & \\
\cline { 1 - 3 } & 1 & 25 & 7 & \\
\cline { 1 - 3 } & 2 & 25 & 10 & \\
\cline { 1 - 3 } & 3 & 25 & 12 & \multirow{2}{*}{70,66} \\
\hline & 1 & 25 & 21 & \\
\hline & 2 & 25 & 15 & \\
\hline & 3 & 25 & 17 &
\end{tabular}

Berdasarkan hasil prosentase kematian larva Aedes aegypti tidak didapatkan hasil konsentrasi yang paling efektif dari berbagai konsentrasi yang diteliti yaitu konsentrasi 5\%, 10\%, 15\%. Dari berbagai hasil yang diperoleh tidak ada yang efektif karena konsentrasi perasan dikatakan efektif apabila dapat membunuh larva $>90 \%$.

\section{Kesimpulan}

a. Kematian rata-rata larva Aedes aegypti dari berbagai konsentrasi yang dilakukan 3 kali replikasi selama 24 jam adalah konsentrasi 5\% dapat membunuh larva 14,66\%, pada konsentrasi $10 \%$ dapat membunuh larva $38,66 \%$, dan pada konsentrasi $15 \%$ dapat membunuh larva 70,66 \%.

b. Hasil uji Anova menunjukkan signifikan $=0.000(<$ 0.05) yang berarti adanya perbedaan kematian larva Aedes aegypti akibat penggunaan berbagai konsentrasi perasan daun jeruk nipis (Citrus aurantifolia), yaitu semakin tinggi konsentrasi perasan daun jeruk nipis yang digunakan maka semakin tinggi jumlah kematian larva Aedes aegypti.

c. Konsentrasi larvasida perasan daun jeruk nipis (Citrus aurantifolia) yang direkomendasikan dapat membunuh 50\% dari sampel larva Aedes aegypti $\left(\mathrm{LC}_{50}\right)$ di laboratorium adalah $23.499 \%$ dan konsentrasi larvasida perasan daun jeruk nipis (Citrus aurantifolia) yang dapat membunuh 90\% dari sampel larva Aedes aegypti $\left(\mathrm{LC}_{90}\right)$ di laboratorium adalah $37.466 \%$.

d. Konsentrasi perasan daun jeruk nipis yang diteliti hanya dapat membunuh larva dengan prosentase paling tinggi yaitu $70,66 \%$. Jadi, dari berbagai konsentrasi yang diteliti tidak ada yang efektif, karena Standar Pengujian Efikasi Pestisida konsentrasi yang efektif $>90 \%$.

\section{Ucapan Terima Kasih}

Dalam menyelesaikan karya tulis ilmiah ini penulis banyak mendapat bantuan baik materiil maupun moril dari berbagai pihak, untuk itu penulis mengucapkan terimakasih kepada pihak Loka Litbang P2B2 Ciamis Jawa Barat yang telah membantu penulis dalam menyelesaikan Karya Tulis Ilmiah, Khomsatun, S.Pd., S.Kes., M.Kes sebagai pembimbing penulis,Ibunda ter-cinta Nuryani Takaryati yang telah mendidik penulis, kedua kakak penulis Imaniar dan Intan yang telah mendukung penulis, teman-teman penulis yang selalu memotivasi penulis. 


\section{Daftar Pustaka}

Adang Iskandar. 1995. Pemberantasan Serangga \& Binatang Pengganggu. Jakarta : Pusdiknakes

Annisa Kurnia, 2014, Khasiat Ajaib Jeruk Nipis dari A- Z untuk Kesehatan \& Kecantikan, Rapha Publishing : Yogyakarta.

Aris Santjaka. 2014. Aplikasi SPSS Untuk Data Penelitian Kesehatan. Yogyakarta: Nuha Medika

Departemen Kesehatan Republik Indonesia. 2007. Ekologi dan Aspek Perilaku Vektor. Direktorat Jenderal Pemberantasan Penyakit Menular Dan Penyehatan Lingkungan Pemukiman : Jakarta

Departemen Kesehatan Republik Indonesia. 2008. Modul Pelatihan bagi Pelatih Pemberantasan Sarang Nyamuk (PSN) DBD dengan Pendekatan Komunikasi Perubahan Perilaku/KKP. Ditjen P2PL : Jakarta.

DIT. JEN. PPM dan PLP, 1987, Pemberantasan Vektor dan Cara Evaluasinya

http://ejournal.litbang.kemkes.go.id/index.php/vk/artic le/view/3326/3336

http://ejournal.litbang.depkes.go.id/index.php/BPK/art icle/view/4147/3912

KEMENKES, 2015, Kasus dan Kematian DBD Indonesia Akhir Tahun 2015 Turun Drastis, DetikHealth

https://health.detik.com/read/2016/01/12/200120/3116 929/763/kemenkes-kasus-dan-kematian-dbdindonesia-akhir-tahun-2015-turun-drastis (diaskes pada tanggal 16 Desember 2016 pukul 18.44)

KEMENTRIAN KESEHATAN RI, 2013, Pedoman Pengendalian Demam Berdarah Dengue Di Indonesia.

Kurnia Agung Indraprasta. 2015. Efektifitas Larvasida Antara Abate, Ekstrak Daun Sirsak (Annona muricata Linn) Dan Ekstrak Daun Sirih (Piper betle Linn) Terhadap Kematian Larva Aedesaegypti Instar 3, Karya Tulis Ilmiah (tidak dipublikasikan) : Poltekkes Kemenkes Semarang.

M. Padmiarso Wijoyo, 2008, Sehat dengan Tanaman Obat, Bee Media Indonesia: Jakarta

Mokhamad Marzulio Kadafi. 2016. Pengaruh Berbagai Dosis Ekstrak Daun Pepaya California (Carica papaya L) terhadap kematian larva Aedes aegypti di Laboratorium Balai Litbang
P2B2 Banjarnegara, Karya Tulis Ilmiah (tidak dipublikasikan): Poltekkes Kemenkes Semarang.

Nurlaeli Juliani. 2016. Efektivitas Ekstrak Daun Sirsak (Annona muricata, L) Sebagai Repellent Nyamuk Aedes aegypti di Loka Litbang P2B2 Ciamis, Karya Tulis Ilmiah (tidak dipublikasikan) : Poltekkes Kemenkes Semarang.

Profil Loka Litbang P2B2 Ciamis, Pangandaran (book) Edisi ketiga 2013

Rahmat Rukmana, 1996, Jeruk Nipis, Kanasius : Yogyakarta

Rina Murdani, 2014, Keefektivan Daya Bunuh Ekstrak Daun Jeruk Nipis (Citrus aurantifolia) Terhadap Kematian Larva Aedes aegypti Instar III, Naskah Artikel Publikasi Ilmiah, Kesehatan Masyarakat : Surakarta

http://eprints.ums.ac.id/29078/10/02._NASKAH_PUB LIKASI.pdf (diaskes pada tanggal 4 Desember 2016 pukul 16.05)

Riska Alfianastuti, 2015, Pengaruh Pemakaian Perasan Daun Belimbing Wuluh (AverrhoabilimbiL). Terhadap Kematian Larva Aedes aegypti Tahun 2015, Karya Tulis Ilmiah (tidak dipublikasikan): Poltekkes Kemenkes Semarang.

Rizka Desi Barliyani, 2014, Pengaruh ekstrak etanolik Daun Jeru Nipis (Citrus aurantifolia (Cristm.)Swingle) Terhadap Mortalitas Larva Aedes aegypti L.(DIPTERA: CULICIDAE), Universitas Gadjah Mada : Yogyakarta.

Soekidjo Notoatmodjo, 2010, Metodelogi Penelitian Kesehatan, Rineka Cipta : Jakarta.

Susweni, 2016, Keefektifan Pemakaian Ekstrak Daun Pepaya Sebagai Insektisida Alami Terhadap Kematian Larva Aedes aegypti Tahun 2016, Karya Tulis Ilmiah (tidak dipublikasikan): Poltekkes Kemenkes Semarang.

Titin, 2009, Efektivitas Ekstrak Daun Pare Terhadap Larva Nyamuk (Momordica charantia) Aedes aegypti, Karya Tulis Ilmiah (tidak dipublikasikan): Poltekkes Kemenkes Semarang.

Tri cahyono, 2014, Pedoman Penulisan Proposal Penelitian Dan Karya Tulis Ilmiah / Skripsi, Purwokerto : Perpustakaan Kampus 7 Politeknik Kesehatan Semarang.

WHO. 1999. Demam Berdarah Dengue. Jakarta : EGC 